\title{
THE Distribution OF TALENT AND THE PATTERN AND CONSEQUENCES OF INTERNATIONAL TRADE
}

\author{
GENE M. GROSSMAN \\ CESIFo WORKING PAPER No. 745 \\ CATEgORY 7: TRADE POLICY \\ JUNE 2002
}

- from the CESifo website: www.CESifo.de 


\title{
THE DisTRIBUTION OF TALENT AND THE PATTERN AND CONSEQUENCES OF INTERNATIONAL TRADE
}

\begin{abstract}
In an economy with imperfect labor contracts, differences in the distribution of talent can be an independent source of comparative advantage. I study a world economy with two activities, one in which an individual's contribution to production can be measured accurately and another in which workers engage in joint production. When individuals have private information about their own talents, the most able workers self-select into the occupation in which their reward best reflects their own performance. I describe an equilibrium in which the country with a more heterogeneous labor force exports the good that is produced by the most talented individuals. In this country, trade exacerbates the "polarization" of labor and often worsens the distribution of income.
\end{abstract}

JEL Classification: F11, D51.

Keywords: labor contracts, diversity, joint production, comparative advantage, income distribution.

Gene M. Grossman

International Economics Section

Department of Economics

Princeton University

Princeton, NJ 08544

USA

grossman@princeton.edu

An earlier version of this paper was entitled "Imperfect Labor Contracts and International Trade." I thank Patrick Bolton, Faruk Gul, Elhanan Helpman, JeanJacques Laffont, Giovanni Maggi, Wolfgang Pesendorfer, Marti Subrahmanyam, Jean Tirole, and especially Avinash Dixit for their help and comments, and the National Science Foundation for financial suppport. 


\section{Introduction}

Workers differ in ability. Those who are endowed with great intelligence, good health, and ample energy, and those who have had the benefit of a supportive upbringing and a quality education, are potentially more productive in a wide range of activities than others who have been less fortunate along some or all of these dimensions. One of the most important functions of the labor market is to allocate the heterogenous pool of talent to the different sectors of the economy.

In a world of perfect labor contracts (and competitive firms, complete markets, etc.), the allocation of talent would be efficient. A worker of given talents, confronting a range of opportunities to work in different sectors, would choose the job that appealed the most. But the 'invisible hand' would guide these choices. The most talented individuals would be led by market forces to undertake those jobs with the greatest social return to talent. And individuals of similar ability would find incentive to toil together whenever complementarities in the production technology dictated the efficacy of their doing so.

Alas, real world labor contracts are rarely perfect. Imperfections arise from informational asymmetries and the costliness of verifying the contingencies that might appear in a contract. A workers often has better information than prospective employers about the factors that determine his own productivity. When prospective employers do not observe all of the relevant aspects of an applicant's ability, an offer cannot be made fully contingent on ability. A firm might wish, then, to link an employee's compensation to his or her performance. But there are at least two potential problems with this. First, an individual's productivity may be difficult to measure, because the technology may require joint inputs from a number of workers. Then a contract could tie payments only to the performance of his team. Second, even this more limited class of contracts may be restricted, if workers cannot readily observe a firm's output or its profits. Piecework and profit-sharing arrangements break down when workers cannot verify employers' claims about joint production or the resulting profits. Firms may be left with little choice but to pay similar compensation to 
workers whose talents differ.

If labor contracts cannot finely distinguish between workers, the allocation of talent may be distorted. To break even, a firm must pay a wage commensurate with the average productivity of its work force. But such an offer induces adverse selection. A uniform contract that suits the average worker will not appeal to one who knows himself to be more productive than average and perceives alternative options that would provide him a greater return on his talent. Firms that are forced to offer uniform contracts will draw disproportionately from the bottom end of the target population of workers (i.e., those with the observable attributes it demands), while the cream of any group of outwardly similar workers will seek activities in which their outputs can be measured or where they themselves retain property rights to the fruits of their labor.

Imperfect employment contracting affects both occupational choice and industry allocation. A talented individual will eschew activities in which individual attribution is difficult and verification of group output is costly. Within an industry, such an individual might prefer specialties that permit measurement of his personal contribution, or, as in the model presented below, occupations that make him the residual claimant on the output produced by a number of workers. And since industries differ in their technologies, the problems posed by imperfect contracting may be more severe in some sectors than in others. In particular, large-scale manufacturing may be at a disadvantage in attracting the most talented individuals as compared to, say, the software, financial or legal sectors, where it may be easier to measure the contributions of individual workers.

In a world of imperfect labor contracts, national differences in the distribution of talent can be an independent source of comparative advantage. Two countries that are otherwise identical may specialize in different activities in a competitive, free-trade equilibrium, if one country has a greater proportion of low-ability workers than the other. Consider, for example, the United States and Japan. It is commonly observed that Japan has a more homogeneous labor force than the United States. 
Suppose the average ability of workers in both countries is the same, and that both countries have access to the same production technologies. Let there be two sectors, one (automobiles) in which a worker's productivity cannot easily be monitored and a second (software) in which attribution is more readily achieved. In Section 2, I show that there will be no trade between these countries if employment contracts can be written that make a worker's pay contingent on his productivity. In other words, differences in the distribution of talent do not generate comparative advantage when perfect contracts are feasible. ${ }^{1}$ But suppose that workers' abilities are not observable to firms and that firms' outputs are not verifiable by employees. Then contracts cannot tie pay to performance. In the United States, a moderately talented individual might be disinclined to enter the industry with team production, because average productivity would be dragged down by those with very low ability. In Japan, the same forces are present, but to a lesser extent. An individual with the same moderate talents might be willing to work in a car plant, if the (average) wage paid to all workers in the sector were not too low. In Section 5, I show that, at a given price, a highability worker may have a greater incentive to join the industry in which his own output is measurable in a country with a large share of low-ability workers than in a country with a smaller share of such workers. Such differences in the incentives for occupational choice create an opportunity for trade. In particular, when there is a uniform distribution of talent in each country, the country that has the greater spread of talent exports the products of attributable efforts and imports the goods that are jointly produced.

There are some important consequences of the trade that derives from differences in distributions of talent in the face of imperfect labor contracting. First, such trade causes a deterioration of the income distribution in the country that imports the jointly-produced good. On the margin, an increase in the relative price of software

\footnotetext{
${ }^{1}$ Grossman and Maggi (2000) show that differences in diversity can be a source of international trade even with perfect information or perfect contracts if, for technological reasons, the talents of team workers are are substitutable in some sectors and complementary in others. This is discussed further in Section 5 below.
} 
induces the most talented workers in the automobile sector to leave that industry and instead produce software. But this degrades the talent pool among those who remain in the import-competing sector, which depresses average productivity and wages there.

Second, trade associated with imperfect labor contracting can exacerbate a preexisting production distortion in the country that imports the good produced by teams. A talented individual choosing between the automobile and software industries does not take into account that his employment would generate external benefits in the former sector, but not in the latter. If he opts to work in the sector with joint production, average productivity there rises and, as we shall see, some of the benefits accrue to individuals besides himself. If he decides to work instead in the sector in which his personal productivity is measurable, the individual captures all of the social returns to his talent. Thus, national income would be augmented by a marginal increase in the number of individuals who choose the industry with team production, starting from the competitive equilibrium. Since trade may encourage further specialization in individualistic production in the country with a more diverse talent pool, it has the potential to reduce national income even as it worsens the distribution of that income. Production subsidies (or tariffs) could reverse these effects, although Pareto improvements are difficult to come by in view of the asymmetries of information that eliminate the possibility of targeted lump-sum compensations.

The remainder of the paper is in six sections. The basic model is developed in Section 2. It has two sectors, one in which output is produced by teams and another in which either individual productivity can be monitored or individuals can work alone. Labor is the sole input to production, but the labor force is heterogeneous. I examine the Walrasian equilibrium with perfect labor contracts, which then serves as a benchmark for what follows. In Sections 3, I characterize the equilibrium occupational choices in a small, price-taking country with imperfect labor contracts. Section 4 explores the links between relative prices, occupational choice, and income distribution. I also establish there the inefficiency of the competitive equilibrium and discuss 
the policy implications of this. Trade patterns are the subject of Section 5, where I consider trade between two large countries that differ only in their distributions of talent. Specifically, I assume that talent is uniformly distributed with the same mean in each of two countries and show that the country with the greater spread of talent imports the good produced by teams. In Section 6, I discuss the relationship of this paper to some others in the literature. Section 7 concludes.

\section{The Model}

The economy has two sectors. In one sector, production is a collective enterprise. A team of workers performs a set of indivisible tasks, with one worker needed for each task. The technology dictates the total number of tasks and thus the size of a production unit. Output generated by a team is $F\left(q_{1}, q_{2}, \ldots, q_{n}\right)$, where $n$ is the number of tasks and $q_{i}$ is the skill of the team member who performs task $i$. The physical quantity of output may vary with the composition of a team or the quality of the product may be different for different teams, with $F(\cdot)$ measuring output in quality-adjusted units. In any event, there are no identifiable outputs of the individual contributors, only the joint product of the team. I will refer to this as the "automobile" industry.

In the other sector, individuals can work alone. This may mean that a worker can produce a finished good or service single-handedly, as when a particular investment adviser handles a client's account, or that an individual's contribution to a group effort can be identified separately, as when some person can take credit for the authorship of a particular piece of software. The important assumption is that each worker's output is measurable and verifiable, so that in principle he could operate on his own. I call this the "software" sector. ${ }^{2}$

\footnotetext{
${ }^{2}$ The designations should not be taken too literally. Although many software firms are small, with one or a few individuals writing specialized code, Microsoft has become a massive company with many team projects. Also, I take liberties in assuming the pervasiveness of synergies in one sector and their complete absence in the other. In reality, some synergies exist between workers in
} 
Both technologies have constant returns to talent. Thus, the potential output of software by an individual of ability $q_{j}$ is $\lambda q_{j}$. Viewed alone, this statement is nothing more than a definition of a unit of talent. But then the operative assumption is that $F(\cdot)$ is homogeneous of degree one when talent is measured in this way. Rosen (1981) and Murphy et al. (1991) have emphasized that "superstars" will be drawn to activities with increasing returns to talent. I do not deny that returns to talent may vary for different activities, or that such considerations may have important implications for the allocation of talent. But there is no a priori reason to associate joint production with decreasing returns to talent, when the abilities of all members of the team are increased together. Accordingly, I make the more neutral assumption that output varies with skill similarly in the two sectors.

I also assume that $F(\cdot)$ is symmetric and set the number of tasks equal to two. The qualitative properties of the model with two members per team are the same as those with larger teams, so there is no need to carry around the extra terms. As for symmetry, it seems obvious that, in fact, skill is more important for some tasks than for others, and that some individuals are especially well suited to perform certain jobs. But the symmetry assumption allows me to focus on issues to do with imperfect contracting without confounding them with considerations of comparative advantage. ${ }^{3}$ In this model, a worker of given talents would be equally adept at performing all jobs in a world of perfect information. All of the predictions about occupational choice stem from the assumed informational asymmetries and the restrictions on feasible contracts.

Finally, I take $F\left(q_{1}, q_{2}\right)$ to be a non-decreasing, twice differentiable, and supermodular function of its two arguments, with an elasticity of substitution between talents that is everywhere less than or equal to one. ${ }^{4}$ Supermodularity means that for any four workers, aggregate output is highest when the more able of the two work-

most productive ventures.

${ }^{3}$ See Mussa (1982), Ruffin (1988), and Matsuyama (1992) for trade models in which workers differ in their relative ability to supply labor to different sectors.

${ }^{4}$ This last assumption requires $F F_{12} / F_{1} F_{2} \geq 1$ for all $q_{1}$ and $q_{2}$. 
ers performing task 1 is teamed with the more able of the workers performing task 2, as compared to the alternative possible pairing (see Milgrom and Roberts, 1990). Together with the symmetry of tasks, it implies that it is efficient to pair the two workers of highest ability and the two of lowest ability, for any conceivable foursome working in the automobile industry. With $F(\cdot)$ twice differentiable, the supermodularity assumption is equivalent to $F_{12} \geq 0$. Thus, it captures the idea that team members' talents are complementary in producing value. Further, the bound on the elasticity of substitution ensures that the complementarities are moderately strong. When the elasticity of substitution is never greater than one, both tasks must be completed at a non-zero level of competence for output to be positive. This seems a reasonable restriction to place on what one might call 'team production.'

The labor force comprises a continuum of individuals. Each individual is endowed with enough time to perform one productive task, be it one of the tasks needed to produce an automobile or the solo task of writing software. The individuals have no other valuable uses for their time. It takes no time, however, to offer contracts, sell output, or pay wages. Therefore, the same individuals who serve as workers conceivably can own and operate firms. The owner of a firm must honor all employment contracts into which he enters. In return, the owner gains property rights to the firm's output. There is a continuum of firms in each industry, and all firm owners behave competitively in the (world) product market.

The distribution of talent is exogenous in the model. I denote by $\Phi(q)$ the fraction of the $L$ individuals in the home country with ability less than or equal to $q$. The distribution has a median $q_{m e d}$, a mean $\bar{q}$, and a range from $q_{\min }$ to $q_{\max }$. When there are two countries, $\Phi^{*}(q)$ will be used to represent the cumulative distribution function in the foreign country, and $L^{*}$ the labor force there. Often, I will take the distributions to be continuous and differentiable. Then $\phi(q)$ and $\phi^{*}(q)$ will denote the derivatives, that is the p.d.f.'s for talent in each country.

I assume that all individuals in both countries have identical and homothetic preferences. These are represented by the utility function $U\left(c_{a}, c_{s}\right)$, where $c_{i}$ is con- 
sumption of good $i$, for $i=a$ (automobiles) and $s$ (software). I also assume for expositional simplicity that individuals are risk neutral, so that $U(\cdot)$ is homogeneous of degree one. Nothing of importance hinges on this assumption.

In the remainder of this section, I describe the equilibrium that would emerge in a world of perfect information. If individuals could readily observe one another's ability, then employers could link compensation to an employee's talent level. In such a setting, there would exist separate markets for workers of each ability and a different market clearing wage for each level of talent level. Such a setting admits a competitive, Walrasian equilibrium, the properties of which are well known.

In a Walrasian equilibrium, resource allocation maximizes the value of aggregate output given prices. The maximization of value in turn demands productive efficiency. Here, efficiency requires positive assortative matching in the automobile industry. ${ }^{5}$ The equilibrium wages must be such as to make employers of automobile workers indifferent between the various teams they might assemble, but all teams will comprise two workers of identical ability. Of course, in equilibrium, there is free entry of employers, so firm owners earn zero profits.

Let $f \equiv F(1,1) / 2$. Then, since $F(\cdot)$ has constant returns to talent, $2 f q$ is the potential output of automobiles by a pair of workers of talent $q$. The same two workers could instead produce $2 \lambda q$ units of software. With efficient matching, a worker's productivity is proportional to his talent, regardless of the sector of his employment. This means that each country has a linear production possibility frontier with a slope of $-f / \lambda$.

In the Walrasian equilibrium, the allocation of talent is indeterminate. So too is the ownership of firms. The market clearing contracts pay wages that are proportional to ability. A worker of ability $q$ can earn $\lambda p q$ by taking a job in the software industry and $f q$ for one in the automobile industry, where $p$ is the relative price of software in terms of autos. As in any Ricardian setting, the equilibrium price must be $p=f / \lambda$ for positive output of both goods. Then each worker is indifferent as to his sector

\footnotetext{
${ }^{5}$ This follows directly from the definition of supermodularity and the symmetry assumption; see Kremer (1993) or Grossman and Maggi (2000).
} 
of employment. Automobile firms may be owned by one of the team members, who pays $f q$ to his partner. Or the firm may be owned by a third party, who pays $f q$ to each member of the team. In either case, profits are nil. Of course, market forces do determine the aggregate allocation of talent to each sector, which must be such that product markets clear.

What about international trade? With perfect information, the model gives rise to a Ricardian trade equilibrium for countries that share identical technologies. Each country has a production possibility frontier with slope $-f / \lambda$ and the same relative demands for the two goods. Consequently, the benchmark equilibrium has no trade.

\section{$3 \quad$ Imperfect Labor Contracts}

Now suppose that an individual's ability is not observable and that a team's output cannot be verified. For example, it may be difficult for a court to assess the quality of an automobile or to ascertain which cars were produced by a given team. Then contracts linking pay to productivity would be impossible to enforce. ${ }^{6}$ Potential employers have no choice but to offer contracts with fixed wages. These contracts are imperfect here, because they cannot be used to generate the efficient matches in the automobile industry. In this section, I characterize the general equilibrium for a small country that takes world prices as given.

It is necessary first to specify the details of how the labor market with imperfect contracting operates. I model this market as a two-stage, industry-choice-cum-auction

\footnotetext{
${ }^{6}$ In Grossman (1998) I examine an intermediate situation in which workers' talents are not observable, but workers can monitor and verify the (quality-adjusted) output of any team. When output is verifiable, employers can write contracts based on team producitivity. I show that, with no other sources of uncertainty or incomplete information, such contracts are enough to induce the efficient matches. Thus, performance-based contracts yield a competitive equilibrium with an efficient allocation of talent and no trade. However, this result is not robust to the introduction of uncertainty in the production process, if workers are risk averse. One could study the imperfect performance-based contracts that arise when output is verifiable but production processes are uncertain and workers are risk averse; here, instead, I assume that output cannot be verified.
} 
game. In the first stage, each individual makes an irrevocable choice of industry. Let $L_{s}$ denote the measure of individuals that elect to produce software; I take some literary license in calling them "entrepreneurs." The remaining $L_{a}=L-L_{s}$ individuals enter a hiring hall, where teams for producing automobiles are formed. In the hiring hall, each individual submits a bid for a partner. Bids take the form of unconditional wage offers. The highest fifty percent of the bids are designated as "winners," the rest as "losers." A winning bidder becomes a firm owner; i.e., he becomes a residual claimant with property rights to the output of his team. Each such firm owner is committed to pay his partner the amount of his bid. With some abuse of terminology, I will refer to the winning bidders as the "managers" of the firms. The losing bidders are assigned randomly to firms. These employees, or "workers," earn a fixed wage for their efforts. ${ }^{7}$

In the equilibrium with imperfect contracts, individuals sort themselves by talent level into the different industries and roles. The basis for this sorting is illustrated in Figure 1, which plots income as a function of ability level for the three different options open to any individual.

In the figure, the curve $W W$ shows what an individual of talent $q$ can earn if he elects to enter the automobile industry with the expectation of being hired as a worker there. The height of the horizontal line reflects the collective choices of all members of the labor force. But, no matter what choices are made and what equilibrium wage rate $w$ results, the option to become a worker affords any individual the opportunity to earn a fixed income that is independent of his talent level.

\footnotetext{
${ }^{7}$ Notice that the owner of each firm is a member of the production team. I have specified the auction process so that this must be true, but there are also good economic reasons for it. If a third-party owner were to bid for two employees, such an individual would not know the ability of either one. Such a potential owner would face an informational disadvantage relative to the workerowners, who at least know their own ability. It will turn out that, at the prevailing equilibrium wage, any third-party owner of an automobile firm who might contemplate submitting a (winning) bid for a pair of employees would face an expected shortfall of revenues relative to costs. Thus, the model provides an endogenous motive for "inside ownership," with some team members becoming residual claimants and others serving as their employees.
} 


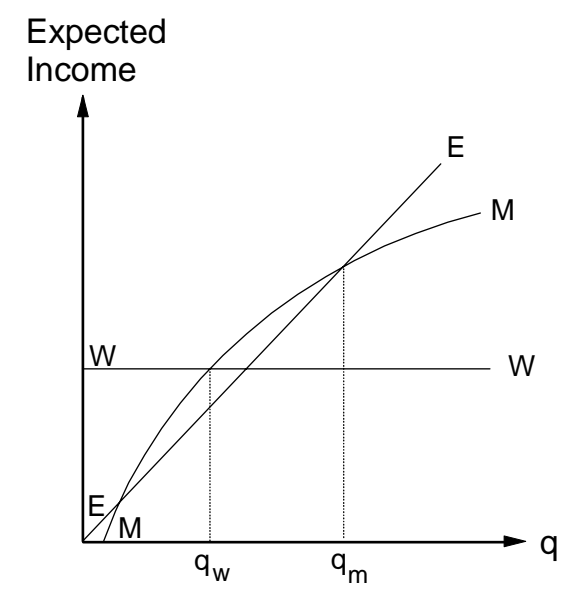

Figure 1: Occupational Choice

The curve $M M$ shows the expected income available to one who enters the automobile industry with the intention of becoming a manager. Such a manager faces uncertain prospects, because he commits to pay a fixed wage while his gross earnings depend on the identity of the partner with whom he is matched. But for any pool of potential employees, a prospective manager can compute the expected output of a team on which he might participate. Expected income is just the difference between expected output and the promised wage. The expected income of an individual qua manager is an increasing function of ability, because managers themselves perform one of the tasks required for joint production. Potential income decreases with $w$, because the manager must pay this amount to his prospective employee. Finally, the expected income of a manager reflects all of the occupational choices, inasmuch as these choices determine the composition of the labor pool from which the manager draws his partner.

Finally, the curve $E E$ depicts the income opportunity for one who elects to become 
an entrepreneur. An entrepreneur produces a quantity of software in direct proportion to his talent level. Therefore, the potential income from this occupation is a linear function of ability, and reflects as well the world relative price $p$ of software.

In the figure, I have depicted the $M M$ curve as a concave function of an individual's ability. This must be true for all possible combinations of occupational choices, because for any given pool of potential workers, the expected output of a manager and his randomly assigned partner is a concave function of the manager's own talent level. I have also drawn the $M M$ curve as passing above the (unique) intersection of the $W W$ and $E E$ curves. I will later argue (mostly in Appendix A) that this must be true in any equilibrium in which both goods are produced. It follows that there is a similar sorting of talent in any equilibrium with incomplete specialization. In such an equilibrium, individuals with talent below some cut-off level $q_{w}$ opt to become workers and earn a fixed wage. Those with talent levels between $q_{w}$ and $q_{m}$ choose to be managers in the automobile sector. And the most able individuals - those with talent levels above $q_{m}$ - produce software, where their personal productivity is fully reflected in their earnings.

When talent is sorted in the manner described, an individual with ability $q_{w}$ must be indifferent in equilibrium between becoming a worker and becoming a manager. As a worker, he would earn a wage $w$. As a manager, he would draw a random partner from among all those in the pool of employees; i.e., those with a talent level less than or equal to his own. Each manager pays his employee a wage $w$. Therefore, an individual with talent $q_{w}$ is indifferent between the two occupations if and only if

$$
w=\frac{1}{\Phi\left(q_{w}\right)} \int_{q_{\min }}^{q_{w}} F\left(q_{w}, q\right) d \Phi(q)-w
$$

Similarly, an individual with talent $q_{m}$ must face similar earnings prospects as a manager and as an entrepreneur. In the former occupation, he draws from the same pool of potential partners as do other managers. As an entrepreneur, he stands to earn $\lambda p q_{m}$ from his potential output of $\lambda q_{m}$ units of software. Thus, in an equilibrium 
with incomplete specialization, it must be that

$$
\lambda p q_{m}=\frac{1}{\Phi\left(q_{w}\right)} \int_{q_{\min }}^{q_{w}} F\left(q_{m}, q\right) d \Phi(q)-w .
$$

Finally, the number of workers in the automobile sector must match the number of managers, since each team comprises one worker and one manager. The number of workers is $\Phi\left(q_{w}\right)$ when all those with talent levels between $q_{\min }$ and $q_{w}$ select this occupation. The number of managers is $\Phi\left(q_{m}\right)-\Phi\left(q_{w}\right)$ when those with abilities between $q_{w}$ and $q_{m}$ opt for management positions. Thus,

$$
\Phi\left(q_{w}\right)=\Phi\left(q_{m}\right)-\Phi\left(q_{w}\right)
$$

in any equilibrium.

Equations (1), (2) and (3) are three equations for the variables $q_{w}, q_{m}$, and $w$, parameterized by $p$. When they have a solution with $q_{\max }>q_{m}>q_{w}>q_{\min }$ and $w \geq 0$, they describe an equilibrium in a small economy that faces the relative price $p$. The equilibrium is supported by the following bidding strategies for those who enter the hiring hall in the automobile sector. Suppose there is a measure $L_{a}$ of individuals in the hall and let $\tilde{q}\left(L_{a}\right)$ denote the median talent level among the $L_{a}$ least talented members of the labor force. Each individual in the hall with talent above $\tilde{q}\left(L_{a}\right)$ bids the wage that would make an individual with talent $\tilde{q}\left(L_{a}\right)$ indifferent between being an employer and an employee. Each person with talent below $\tilde{q}\left(L_{a}\right)$ bids the wage that leaves him personally indifferent between working as an employee or hiring a random partner from the suspected employee pool at that wage. With these strategies, when the hiring hall does indeed attract the $L_{a}$ least talented individuals in the economy, no one in the hall has any incentive to deviate. The more talented half are the winning bidders. Each manager pays just what is needed to hire an employee, but nothing more. A higher bid would only serve to raise his wage bill (since he is anyway a winner, and the set of losers would not change), while a lower bid would drop him from the winning set. Since the designated winning bidders have talent at least as great as the suspected median in the group, each strictly prefers to hire another at the specified wage than to be hired himself. As for the losing bidders, they cannot 
benefit by bidding more (since they have bid their reservation wages), nor do they have any reason to bid less. ${ }^{8}$

To ensure that a solution to equations (1) - (3), when it exists, characterizes an equilibrium for the small open economy, we need to verify that each individual (weakly) prefers his designated occupation to every alternative. Clearly, this is so when the $W W, M M$, and $E E$ curves are aligned as in Figure 1. So, what we need to check is that the $M M$ curve passes above the intersection of the $W W$ curve and the $E E$ curve, as was previously presumed. If it does not, then a group of individuals with talent just greater than that of the workers could earn more as entrepreneurs in the software industry than as managers of automobile plants. But this would contradict my supposition about the equilibrium sorting of talent. However, I prove in Appendix A that there can be no equilibrium in which some individuals who opt to work in the software industry have less ability than others who choose to manage automobile plants. The proof makes use of the assumption that the elasticity of substitution between talents in the production function for automobiles is everywhere less than or equal to one. This assumption is sufficient (but not necessary) to rule out an equilibrium configuration in which the $M M$ curve passes below the intersection of the $W W$ curve and the $E E$ curve.

A solution to (1) - (3) with $q_{\max }>q_{m}>q_{w}>q_{\min }$ and $w \geq 0$ exists if and only if

\footnotetext{
${ }^{8}$ Notice that no third party would wish to hire a pair of workers for the amount of the winning bids, because the expected productivity of two random hires from among a worker pool comprising the least talented $L_{a} / 2$ workers is less than twice the wage that would leave the median in the group indifferent between serving as a worker or as a manager.
} 
$p$ falls between $p_{a}$ and $p_{s}$, where ${ }^{9}$

$$
p_{a}=\frac{2 \int_{q_{\min }}^{q_{\text {med }}} F\left(q_{\max }, q\right) d \Phi(q)-\int_{q_{\min }}^{q_{\text {med }}} F\left(q_{\text {med }}, q\right) d \Phi(q)}{\lambda q_{\max }},
$$

and

$$
p_{s}=\frac{f}{\lambda}
$$

and $q_{m e d}$ is the median talent level in the labor force. Thus, $p_{a}$ and $p_{s}$ are the limits on the relative price of software that allow for an equilibrium with incomplete specialization. When $p<p_{a}$, the most talented individual in the labor force earns more by hiring a random partner from among those in the bottom half of the talent distribution than he could by producing software. ${ }^{10}$ Then the economy specializes in the production of automobiles. When $p>p_{s}$, the least talented worker can earn more by producing software than he can earn by entering the automobile sector and matching with another whose talent is exactly like his own. ${ }^{11}$ Then the economy specializes in producing software.

Finally, we observe that the solution to (1) - (3) need not be unique. That is, for a general distribution function $\Phi(q)$ and an arbitrary relative price $p$, there may be several (but always an odd number of) different allocations of talent with the property

\footnotetext{
${ }^{9}$ The proof of this statement is in Appendix A. Note that $p_{s}>p_{a}$ if and only if

$$
f q_{\max }>2 \int_{q_{\min }}^{q_{\text {med }}}\left[F\left(q_{\max }, q\right)-\frac{1}{2} F\left(q_{\text {med }}, q\right)\right] d \Phi(q) .
$$

But $f q_{\max }=2 \int_{q_{\min }}^{q_{\operatorname{med}}} \frac{1}{2} F\left(q_{\max }, q_{\max }\right) d \Phi(q)$, so $p_{s}>p_{a}$ if and only if $\int_{q_{\min }}^{q_{\text {med }}} I(q) d \Phi(q)>0$, where $I(q) \equiv \frac{1}{2} F\left(q_{\max }, q_{\max }\right)+\frac{1}{2} F\left(q_{\text {med }}, q\right)-F\left(q_{\max }, q\right)$. Now, $I\left(q_{\text {med }}\right)>0$ by the supermodularity of $F$, and $I^{\prime}(q)=\frac{1}{2} F_{2}\left(q_{\text {med }}, q\right)-F_{2}\left(q_{\max }, q\right)<0$. Therefore $\int_{q_{\min }}^{q_{\operatorname{med}}} I(q) d \Phi(q)>0$, which implies $p_{s}>p_{a}$.

${ }^{10}$ The expected output of a manager with abiltiy $q_{\max }$ who hires randomly from among those in the bottom half of the talent distribution is $2 \int_{q_{\min }}^{q_{\operatorname{med}}} F\left(q_{\max }, q\right) d \Phi(q)$. This provides the manager with a higher expected income in the autombile sector than the amount $\lambda p q_{\max }$ that he could earn as an entrepreneur, in view of $p>p_{a}$ and $w=\int_{q_{\min }}^{q_{\text {med }}} F\left(q_{\text {med }}, q\right) d \Phi(q)$. This value for $w$ is implied by the condition of indifference for the marginal worker.

${ }^{11}$ Two individuals of talent level $q_{\text {min }}$ who pair in the automobile sector as manager and worker will each earn $f q_{\min }$. This is less than $\lambda p q_{\min }$ when $p>p_{s}$.
} 
that no individual has an incentive to make a different choice of occupation or bid differently in the hiring hall, given the anticipated behavior of others. For each such

allocation there are corresponding outputs $x_{a}=\frac{L}{\Phi\left(q_{w}\right)} \int_{q_{w}}^{q_{m}}\left[\int_{q_{\min }}^{q_{w}} F(z, q) d \Phi(q)\right] d \Phi(z)$ and $x_{s}=\lambda L \int_{q_{m}}^{q_{\max }} q d \Phi(q)$ that determine, together with aggregate demand, the pattern of world trade.

\section{Consequences of International Trade}

In the first part of this section, I study the consequences of international trade in a small country. I do so by examining the relationship between relative prices and the expected income of individuals at all levels in the talent distribution. In the second part of the section, I investigate the normative properties of the free-trade equilibrium. I show that the equilibrium marginal rate of transformation between software and automobiles falls short of the world relative price of software. It follows that a small subsidy to automobile production would boost the value of national income at international prices even as it would improve the distribution of that income.

\subsection{Exogenous changes in relative price}

Consider the effects of an increase in $p$, as for example when the terms of trade improve in a country that exports software. Figure 2 proves useful for this purpose. In this figure, the curve $A A$ (" $A$ " for automobile) depicts combinations of $q_{m}$ and $w$ that satisfy (1) and (3) for a given price $p$ between $p_{a}$ and $p_{s}$. Along this curve, when all individuals with ability less than or equal to $q_{m}$ work in the automobile sector and the most talented half of them are managers, the individual with talent $q_{w}$ is just indifferent between being a worker and being a manager. The curve slopes upward, because the greater is the wage, the more tempting it is to be a worker, and only an individual of greater ability choosing from a more talented employment pool would be indifferent between the two roles. The curve $S S$ (" $S$ " for software) in turn depicts the combinations of $w$ and $q_{m}$ that satisfy (2) and (3); i.e., they make the marginal 


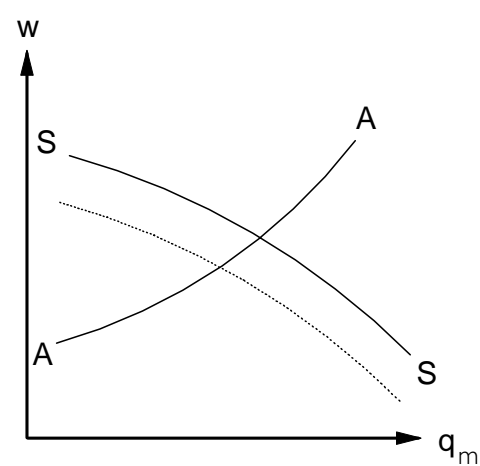

a

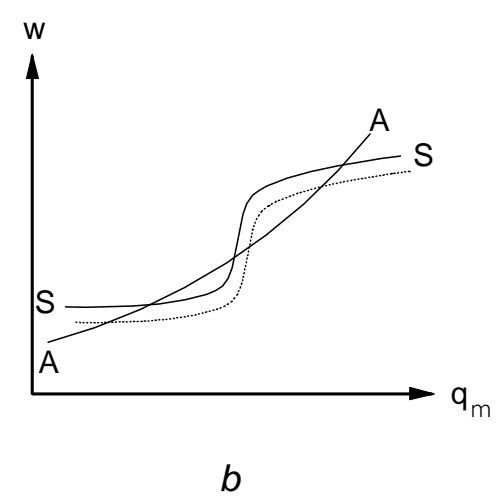

Figure 2: Change in Relative Price 
manager indifferent between entering the software and automobile industries after taking into account who would be in the automobile employment pool at the given $q_{m}$. This curve can slope in either direction, and can be steeper or flatter than the $A A$ curve when it is upward sloping. To see this, note that expected income rises with ability in both sectors. In the software industry, expected income rises exactly in proportion to talent. But in the automobile industry, expected income may rise more than or less than in proportion to the talent of the best manager, once the associated change in the employment pool is taken into account. If the best manager's expected income from running an automobile firm rises less than in proportion to talent after accounting for the change in $q_{w}$, then a new marginal manager with greater talent can be indifferent between industries only if the wage is lower. This gives a downward sloping $S S$ curve, as depicted in panel $a$. If, on the other hand, income for the most talented manager in the automobile sector rises more than in proportion to $q_{m}$ after $q_{w}$ adjusts, then the $S S$ curve slopes upward. The curve must lie above the $A A$ curve at $q_{m}=q_{\min }$ and it must lie below it at $q_{m}=q_{\max }$, but, in principle, it can cross the $A A$ curve several times. ${ }^{12}$ Multiple crossings, such as are depicted in panel $b$, indicate the existence of multiple equilibria, a possibility that was mentioned in the previous section. An increase in the price of software makes employment in the software sector more attractive. An individual with some given talent who was indifferent between managing an automobile plant and producing software before the price change will only be indifferent afterwards if the cost of hiring an employee in the automobile sector is lower than before. Thus, the $S S$ curve shifts downward, as indicated by the dotted curves in the two panels of Figure 2. Meanwhile, the price hike leaves the $A A$ curve unaffected.

When the equilibrium is unique, an increase in the price of software causes $q_{m}$ to fall. This is clear in panel $a$, which depicts a falling $S S$ curve, and it also applies to

\footnotetext{
${ }^{12}$ The fact that $p>p_{a}$ ensures $S S$ above $A A$ at $q_{m}=q_{\text {min }}$. Similarly, $p<p_{s}$ ensures $A A$ above $S S$ at $q_{m}=q_{\max }$.
} 
the case of a rising $S S$ curve that cuts the $A A$ curve once from below. ${ }^{13}$ Intuitively, an increase in $p$ draws individuals into the software sector by improving the prospects there for those who might otherwise operate automobile firms. As the top managers leave the automobile industry, some who were workers must now operate their own firms. That is, $q_{w}$ falls, and with it the average talent of those remaining in the employment pool. The wage rate is equal to one-half the expected output of the least-talented manager and his random partner (see (1)). Since both $q_{w}$ and the average ability of the partner fall, the wage falls as well.

Figure 3 depicts two possible shifts in the talent-income profile. In both cases, the rich get richer, while the poor get poorer! The most talented individuals - those who toiled in the software industry in the original equilibrium - surely benefit from any increase in the relative price of software. Their nominal incomes rise in proportion to $p$, which means that their real incomes rise no matter what they consume. And the least talented individuals - those who are employees in automobile firms in the final equilibrium — surely lose. For these individuals, nominal incomes fall even as consumer prices rise. In panel $a$, the rise in $p$ hurts all those who remain in the automobile sector after the change in relative price. Here the benefits of the terms of trade improvement go only to the society's elite. Panel $b$ shows the possibility that a group of relatively low-ability managers in the automobile industry might benefit from a rise in $p$. For these individuals, the cost savings from the drop in wages might outweigh the (expected) loss of productivity from the degradation of the employment pool. $^{14}$

Panel $b$ of Figure 3 shows the effects of an increase in the price of software when there are multiple equilibria. Starting from any equilibrium at which the $S S$ curve

\footnotetext{
${ }^{13}$ If the curves cross only once, the $S S$ curve must be flatter than the $A A$ curve at the point of intersection, by the argument of the previous footnote.

${ }^{14}$ Note that the decline in the wage benefits all managers of automobile firms equally, whereas the degredation of the talent pool hurts most the managers with the greatest talent. Therefore, it is the least talented of the original managers, if any, who stand to benefit from the net effect of the two.
} 


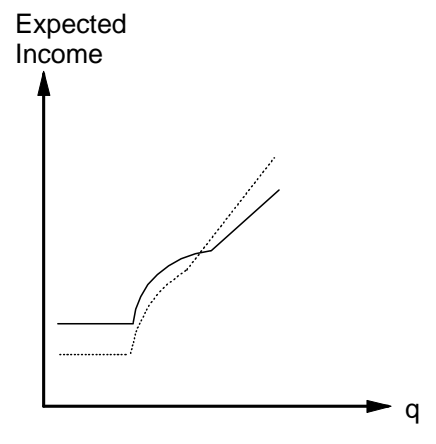

$a$

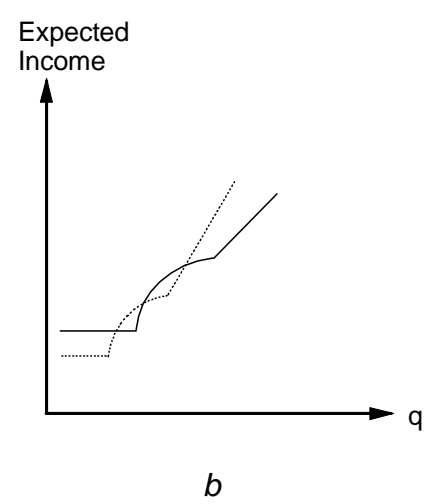

Figure 3: Relative Price and Income Distribution 
cuts the $A A$ curve from below, the comparative statics are qualitatively like the ones I have just described; employment in the software sector expands, output of software rises, and the wage rate falls. All of these responses are reversed when the $A A$ curve is steeper than the $S S$ curve at the initial equilibrium. It is worth noting, however, that such equilibria are unstable for an ad hoc adjustment process under which the wage rises when the median individual in the automobile industry earns more as a worker than as a manager (given $q_{m}$ ) and the automobile sector contracts when the most talented manager could earn more in that sector than he could by hiring an employee, given $w$.

\subsection{Inefficiency of the free-trade equilibrium}

I will now argue that a subsidy to automobile producers would expand the size of the economic pie even as it redistributes income from those who earn the most to those who earn the least. ${ }^{15}$ In other words, the size of the software sector in the freetrade equilibrium is larger than that which maximizes the value of national output at international prices.

The argument is straightforward. At the free-trade equilibrium, the least talented software writer produces output worth $\lambda p q_{m}$. If he were to choose instead to enter the automobile industry, his marginal contribution to national income would be $\pi\left(q_{m}\right)+$ $\Omega / 2 \Phi\left(q_{w}\right)$, where $\pi\left(q_{m}\right)$ is the expected income of a manager of talent $q_{m}$, and ${ }^{16}$

$$
\Omega=\int_{q_{w}}^{q_{m}}\left[F\left(z, q_{w}\right)-\frac{1}{\Phi\left(q_{w}\right)} \int_{q_{\min }}^{q_{w}} F(z, q) \phi(q) d q\right] \phi(z) d z .
$$

But $\pi\left(q_{m}\right)=\lambda p q_{m}$, since the marginal manager must be indifferent between the two industries when occupational choices are made to maximize personal income. National income would be augmented by shifting the marginal software writer to the

\footnotetext{
${ }^{15}$ In making this statement, I neglect the possibility that the initial equilibrium is one at which the $A A$ curve cuts the $S S$ curve from below.

${ }^{16}$ Note that $x_{a}=\frac{L}{\Phi\left(q_{w}\right)} \int_{q_{w}}^{q_{m}}\left[\int_{q_{\min }}^{q_{w}} F(z, q) d \Phi(q)\right] d \Phi(z)$. The marginal contribution to national income is $\left(d x_{a} / d q_{m}\right) / \phi\left(q_{m}\right)$, which can be calculated directly using $d q_{w} / d q_{m}=\phi\left(q_{m}\right) / 2 \phi\left(q_{w}\right)$.
} 
automobile industry if and only if $\Omega>0$. In fact, $\Omega$ must be positive, because the term in brackets is the difference in expected output when a manager of talent $z$ teams with the most talented worker compared to when he teams with a randomly selected worker.

I conclude that, when labor contracts are imperfect, private and social incentives diverge. When a talented individual enters into team production, he generates a positive externality. This is because his presence in the industry improves the talent pool there, which raises the average productivity in firms other than his own. In contrast, a talented individual appropriates all of the social benefits when he elects to work alone. A government could subsidize the sector in which an individual's productivity cannot be measured to encourage entry there. Not only would the poorest members of society benefit, but the increase in income would exceed the cost of the (small) subsidy.

\section{Talent Distribution and the Pattern of Trade}

In the last section, I established some properties of a trade equilibrium in a small country with imperfect labor contracts. This section examines the pattern of trade between two large countries. More specifically, I link the trade pattern to differences in the distribution of talent. Once that is done, I will be able to discuss how trade affects income distribution differently in relatively homogeneous versus relatively heterogeneous societies.

I consider the special case in which each country has a uniform distribution of talent and the mean skill level is the same in both two countries. In the foreign country, the range of talents is from $\bar{q}-e^{*}$ to $\bar{q}+e^{*}$. In the home country, talents run from $\bar{q}-e$ to $\bar{q}+e$, with $e>e^{*}$. Thus, the home country has a more diverse labor force than the foreign country, and a greater fraction of individuals with very low ability. We will see how this leads the home country to export software.

In a free-trade equilibrium, the countries face the same relative world price. We can ascertain the trade pattern by examining how the relative supplies of the two 


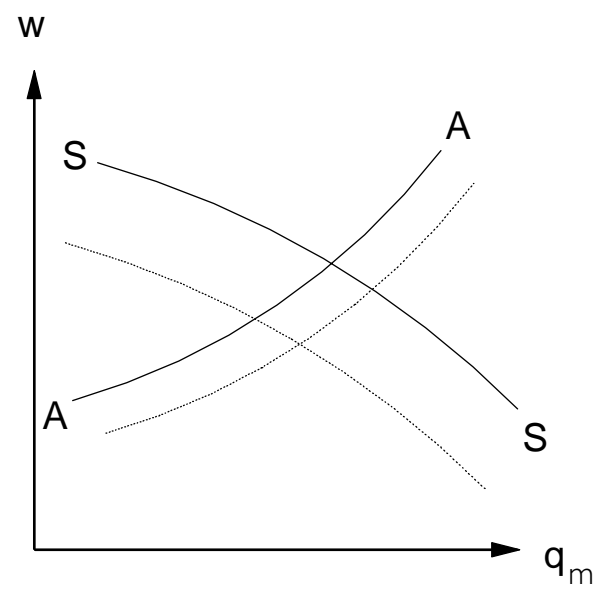

Figure 4: Distribution of Talent and Pattern of Specialization

goods respond to a change in $e$ at a given price $p$.

To this end, consider Figure 4. The solid lines in the figure show the determination of the marginal manager and the wage rate for an initial value of $e$. The two curves have the same interpretation as in Figure 2; $A A$ depicts combinations of $q_{m}$ and $w$ that leave the individual with talent $q_{w}$ indifferent between being a worker and a manager when half of the individuals in the automobile sector are managers, while $S S$ shows combinations of $q_{m}$ and $w$ that make the marginal manager indifferent between entering the two sectors. Recall that the $A A$ curve slopes upward no matter what the distribution of talent. It is relatively easy to show that the $S S$ curve must slope downward when talent is uniformly distributed.

A spread in the distribution of talent shifts both curves downward. The new locations are indicated by the dotted lines. The shift in the $A A$ curve can be understood as follows. For a given value of $q_{m}$, an increase in $e$ reduces $q_{w}$. If $q_{m}$ were unchanged, the new least-talented manager would be less productive than before, and, moreover, he would draw from a less talented pool of workers. For this individual to be attracted into management, the wage would need to be lower than before. As for the $S S$ curve, 
the reasoning is similar. For an individual with talent $q_{m}$, expected revenues in the automobile sector decline with an increase in $e$, because the average ability of the prospective partner is lower. The individual who was initially the marginal manager can be indifferent between the two industries only if the wage rate also is lower.

The algebra reveals that the $S S$ curve shifts down by more. ${ }^{17}$ Thus, an increase in the uniform spread of talent at a given price causes some individuals who would have worked in the team sector to opt instead for production where their productivity can be measured. The downward shift in $q_{m}$ occurs because the fall in the average ability of a prospective hire outweighs the decline in the wage. This reflects the assumed complementarities in team production. Since the least-talented manager is relatively close in ability to his expected partner, the downward pressure on the wage caused by the dilution of the worker pool is modest compared to the loss of productivity for the most-talented manager, for whom the reduction in a partner's talent is especially damaging.

It can be shown, in fact, that $d q_{m} / d e<-1$; i.e., the range of individuals who choose the automobile sector contracts, even as the number of persons with any given talent level falls. Thus, there are fewer individuals in the automobile sector after the mean-preserving spread, and the average ability of both workers and managers is diminished. This implies that a uniform spread in talent reduces output of automobiles at a given price.

In the software sector, the number of writers expands, but average ability falls. Output would remain the same if $d q_{m} / d e$ were equal to minus one. Then the number of software writers would be unchanged, and the average ability would be the same as well. Since $d q_{m} / d e<-1$, the sector is even larger than the size that would keep output constant. Although the extra software writers are less productive than the others in the industry, they still produce positive output. Therefore, a spread in the talent distribution increases aggregate software production.

To summarize, the larger pool of very low skilled workers in the country with the

\footnotetext{
${ }^{17}$ All of the algebra is relegated to Appendix B.
} 
greater spread of talents generates a greater disincentive for a talented individual to enter into team production. Such an individual would anticipate being paired with a less able partner in the country with the fatter bottom tail in the talent distribution. Although the wage he would pay his partner would be lower in this country as well, the loss in expected productivity would outweigh the cost savings. We find that the country with the greater diversity of talents produces relatively fewer automobiles, and of course relatively more software. With identical and homothetic preferences, this country imports automobiles and exports software in a free-trade equilibrium.

What are the effects of the trade induced by imperfect labor contracting? Compared to autarky, the relative price of software is higher in the country that exports software. We have seen that a rise in $p$ raises the income of the most talented (and richest) individuals, while reducing the wage for those with the least ability. Thus, trade contributes to a further polarization of society in a country that has a relatively diverse labor force. Just the opposite is true in the relatively homogeneous society; the range of incomes was relatively narrow to begin with, and trade narrows this range even further. Finally, note that trade exacerbates the informational externality in the country with a greater spread of talents, whereas it alleviates this externality in its trade partner.

\section{Related Literature}

Murphy et al. (1991) contains an excellent discussion of the factors that guide the allocation of talent. In their modeling of occupational choice, these authors follow Rosen (1981) in emphasizing returns to scale. They point out that the ablest people tend to choose sectors with large potential markets and weak diminishing returns to scale. This allows a "superstar" to spread his ability advantage over the largest possible scale of operations. Murphy et al. present a model, based on Lucas (1978), in which there is a continuum of individuals with heterogeneous abilities. Each production unit has a single manager and an endogenous workforce, where the productivity of the workforce is proportional to the ability of the manager. In this setting, the 
most talented individuals become managers, because their extra profits from a given workforce are more than in proportion to their ability advantage, and because the abler managers can operate larger firms and so spread their talent over a larger scale.

Murphy et al. certainly recognized the importance of contract considerations in determining what occupations and sectors would be attractive to talented persons. In fact, they wrote that

differences in contracts between industries are probably as important or more important than diminishing returns to scale [for determining the allocation of talent]. In industries where it is easy to identify and reward talent, it might be possible to pay the able people the true quasi rents on their ability and so attract them. ... Starting one's own company is obviously the most direct way to capitalize on one's talent without sharing the quasi rents. ... Also, talent will flow into sectors with less joint production, where it is easier to assign credit and reward contributions. (p.513)

In this paper I have developed a general equilibrium model of occupational choice in which imperfect contracting governs the choice of job and sector by individuals of different abilities. My model complements that of Lucas (1978) where potential scale plays the critical role.

The issues to do with adverse selection in my analysis call to mind some of the literature on efficiency wages. In particular, Weiss (1980, 1991) and Malcomson (1981) present models in which firms that cannot observe workers' abilities offer "extra" wages in order to make their jobs appealing to a wider range of talents. ${ }^{18}$ The focus of these papers is on the unemployment that could result when all firms attempt to pay above-market wages in order to improve their applicant pool. Here, I have intentionally adopted an institutional setting in which efficiency wages are impossible. First, I have assumed ex post immobility across sectors, which means that

\footnotetext{
${ }^{18}$ Theirs are not general equilibrium models of occupational choice in the sense that mine is, inasmuch as the indentities of the residual are not determined endogenously in the model.
} 
the population of workers in the automobile industry is fixed at the time that contracts are tendered. Second, I have modeled the labor market as a multi-winner auction, which precludes talented managers from offering high wages and thereby attracting applications from individuals who would otherwise serve as managers themselves. My intent here was to focus on the allocation of talent in a simple model with imperfect contracts, not to study the determinants of unemployment. Since perfect matching could never result even if firms were to offer efficiency wages, it seemed best to abstract from the complications that such offers introduce. ${ }^{19}$

My analysis of the trade equilibrium bears a family resemblance to that in Clemenz (1995). Clemenz studies a two-sector model in which firms can observe a worker's productivity in one sector but not the other. In the sector with unobservable productivity, firms pay efficiency wages. Those who cannot secure jobs in this sector at the above-market clearing wage find employment ex post in the other sector. Clemenz investigates the free-trade equilibrium that results when there are two types of workers in each country. He finds that the country with the greater proportion of high-ability individuals has a comparative advantage in the sector where information is imperfect. He also concludes, like me, that the equilibrium allocation of talent is inefficient, and that trade can bring harm to one of the countries by causing its sector with unobservable productivity to contract.

This paper also relates to previous research on the matching of workers in firms. In particular, Kremer (1993) and Legros and Newman (1997) have studied the sorting generated by a competitive labor market when the production process requires that several individuals interact and the tasks performed by each are complementary in producing output. Kremer and Maskin (1996) document the growing segregation of American workers by skill and the absolute decline in wages of low-skill workers. They use a model with complementarities between asymmetric tasks to explain these

\footnotetext{
${ }^{19}$ In a setting in which talented managers can offer high wages to attract a more talented pool of applicants, there would still be no way to prevent the less talented from applying for the high-wage jobs. Thus, perfect matching of individuals of like ability in the automobile industry could not be an equilibrium outcome.
} 
observations, which they ascribe ultimately to an increase in both the mean and the dispersion of talents in the U.S. labor force. My results suggest that growing trade with countries that have more homogeneous populations than the United States can account for many of the same observations.

Like in this paper, Grossman and Maggi (2000) draw a link between the diversity of talent in a country's labor force and the pattern of its international trade. But they emphasize technological differences in the interaction between workers in different sectors. In some industries, different productive activities may be complementary, as suggested by Kremer (1993). In other industries, different activities may

be substitutable in creating output; for example, value may be very high when one or a small number of tasks is performed especially well. If this is true, then a country with a more diverse labor force has a comparative advantage in the sector in which there is substitutability between tasks. Since substitutability often makes working alone optimal, the technological explanation of the trade pattern complements the contracting story offered here.

\section{Conclusions}

Employment contracts take different forms in the different sectors of an economy. In some sectors, individuals can reap enormous gains if their contributions prove highly valuable. In other sectors, a narrower range of rewards is possible. Often these latter are the sectors where it is difficult to attribute profits to individuals. Differences in contracts play an important and neglected role in the allocation of resources.

In this paper, I have developed a simple general equilibrium model with imperfect labor contracts. In one sector, teams produce output the value of which cannot be verified in court. In the other sector, individuals contributions are readily observable, or individuals can work alone. The most talented individuals prefer the second type of industry, because they can capture greater returns to their ability there. This leaves those with moderate or lesser talents to enter into team production.

When countries differ in the compositions of their labor forces, the pressures for 
this type of segregation by skill vary. The ablest individuals have the greatest incentive to separate themselves when the difference between their own skill and that of their (outwardly similar) compatriots is substantial. While these incentives are present even in a relatively homogeneous society, they are less severe there. It follows that diversity breeds comparative advantage in the face of private information about ability and imperfect labor contracting. A country with a relatively heterogeneous labor force will export goods produced by individual (or attributable) efforts and import those produced by teams. The growing U.S. comparative advantage in financial services and software and the continuing decline of its Rust Belt can perhaps be understood in these terms.

The polarization that accompanies growing trade with more homogeneous societies has a social cost. As the most able people opt for individualistic activities, the talent pool available to teams is diminished. This lowers average productivity in the team sector and drives down wages there. Thus, trade benefits the most talented individuals in the diverse country at the expense of those who are least well off.

My analysis has employed a number of simplifying assumptions. In reality, there are varying degrees of observability of output and profits, and a variety of contract provisions that tie pay to observable performance measures. For example, executives in publicly traded firms often receive stock options as part of their compensation packages. The value of these options varies automatically with the market's assessment of the performance of the firm, though the options do not reflect exactly the executive's personal productivity. An interesting extension of this paper would expand the richness of the contract space to allow finer predictions about the intersectoral allocation of talent. 


\section{References}

[1] Clemenz, Gerhard (1995), “Adverse Selection in Labor markets and International Trade," Scandinavian Journal of Economics, 97, 73-88.

[2] Grossman, Gene M. (1998), "Imperfect Labor Contracts and International Trade", Discussion Paper in Economics No. 204, Woodrow Wilson School of Public and International Affairs.

[3] Grossman, Gene M. and Maggi, Giovanni (1998), "Diversity and Trade", American Economic Review, 90, 1255-1275.

[4] Kremer, Michael (1993), "The O-Ring Theory of Economic Development," Quarterly Journal of Economics, 108, 551-575.

[5] Kremer, Michael and Maskin, Eric (1996), "Wage Inequality and Segregation by Skill," Harvard Institute of Economic Research Discussion Paper No. 1777, Harvard University.

[6] Legros, Patrick and Newman, Andrew F. (1997), "Monotone Matching in Perfect and Imperfect Worlds," Université de Liège, mimeo.

[7] Lucas, Robert E., Jr. (1978), "On the Size Distribution of Business Firms," Bell Journal of Economics, 9, 508-523.

[8] Malcomson, James M. (1981), "Unemployment and the Efficiency Wage Hypothesis," Economic Journal, 91, 848-866.

[9] Matsuyama, Kiminori (1992), "A Simple Model of Sectoral Adjustment," Review of Economic Studies, 59, 375-388.

[10] Milgrom, Paul and Roberts, John (1990), "The Economics of Modern Manufacturing: Technology, Strategy, and Organization," American Economic Review, $80,511-528$. 
[11] Murphy, Kevin M., Shleifer, Andrei, and Vishny, Robert W. (1991), "The Allocation of Talent: Implications for Growth," Quarterly Journal of Economics, $106,503-530$.

[12] Mussa, Michael (1982), "Imperfect Factor Mobility and the Distribution of Income," Journal of International Economics, 12, 125-141.

[13] Rosen, Sherwin (1981), "The Economics of Superstars," American Economic Review, 71, 845-858.

[14] Ruffin, Roy (1988), "The Missing Link: The Ricardian Approach to the Factor Endowments Theory of Trade," American Economic Review, 78, 759-772.

[15] Weiss, Andrew (1980), "Job Queues and Layoffs in Labor Markets with Flexible Wages," Journal of Political Economy, 88, 526-538.

[16] Weiss, Andrew (1991), Efficiency Wages: Models of Unemployment, Layoffs, and Wage Dispersion, Princeton: Princeton University Press. 


\section{Appendix A}

In this appendix I prove that, for $p \in\left(p_{a}, p_{s}\right)$, there exists an equilibrium with incomplete specialization in which every individual in the software sector has greater ability than the most able manager in the automobile industry. I also prove that there does not exist any equilibrium in which some individuals in the software industy have less ability than that of the most able manager.

For $p>p_{a}$, the $S S$ curve of Figure 2 lies above the $A A$ curve at $q_{m}=q_{\min }$. For $p<p_{s}$, the $A A$ curve lies above the $S S$ curve at $q_{m}=q_{\max }$. Both curves are continuous. Therefore, when $p \in\left(p_{a}, p_{s}\right)$, the curves must intersect at least once for some $q_{m}$ between $q_{\min }$ and $q_{\max }$. At this intersection, equations (1)-(3) are satisfied and $w>0$. To establish the existence of an equilibrium of the sort described in the text, it remains to verify only that individuals between $q_{w}$ and $q_{m}$ prefer to manage automobile plants than produce software. To this end, I define $\tilde{F}(z) \equiv \frac{1}{\Phi\left(q_{w}\right)} \int_{q_{\min }}^{q_{w}} F(z, q) d \Phi(q)$, which is the expected output of an automobile firm managed by an individual of ability $z$ when the employee pool consists of those whose abililities fall between $q_{\min }$ and $q_{w}$. Then I need to show that $\tilde{F}(z)-w>\lambda p z$ for all $z \in\left(q_{w}, q_{m}\right)$, when $w, q_{w}$, and $q_{m}$ take on the values associated with the solution to equations (1) - (3).

Suppose not. Then, for the values of $w, q_{w}$, and $q_{m}$ that satisfy (1) - (3), the configuration of the $W W, M M$, and $E E$ curves must be as depicted in Figure 5. Define $\hat{q}$ such that $\lambda p \hat{q}=w$. Notice that $\hat{q}<q_{w}$, which, with (1), implies $\tilde{F}\left(q_{w}\right) / 2 q_{w}<\lambda p$. Notice too that the slope of the $M M$ curve at $q_{w}$ exceeds its slope at the (first) intersection with $E E$, which in turn exceeds the slope of $E E$. Thus,

$$
\tilde{F}^{\prime}\left(q_{w}\right)>\lambda p
$$

But

$$
\tilde{F}^{\prime}\left(q_{w}\right)=\frac{1}{\Phi\left(q_{w}\right)} \int_{q_{\min }}^{q_{w}} F_{1}\left(q_{w}, q\right) d \Phi(q) .
$$

Since $F(\cdot)$ is symmetric and has an elasticity of substitution less than one, $q_{w} F_{1}\left(q_{w}, q\right) / F\left(q_{w}, q\right) \leq 1 / 2$ for all $q \leq q_{w}$. Therefore

$$
\frac{1}{\Phi\left(q_{w}\right)} \int_{q_{\min }}^{q_{w}} F_{1}\left(q_{w}, q\right) d \Phi(q)<\frac{1}{\Phi\left(q_{w}\right)} \int_{q_{\min }}^{q_{w}} \frac{F\left(q_{w}, q\right)}{2 q_{w}} d \Phi(q) d \Phi(q)=\frac{\tilde{F}\left(q_{w}\right)}{2 q_{w}}
$$

which is a contradition. It follows that, for $p \in\left(p_{a}, p_{s}\right)$, there exists a solution to (1)-(3) with $w>0$ and $\tilde{F}(z)-w>\lambda p z$ for all $z \in\left(q_{w}, q_{m}\right)$.

Now suppose that there exists an equilibrium with incomplete specialization in which some individuals in the software industry have less ability than that of the most able manager. In such an equilibrium, the allocation of labor must be as shown in Figure 6. The least talented individuals with $q<\hat{q}=w / \lambda p$ are workers in the automobile industry. Those with $q \in\left(\hat{q}, q_{a}\right)$ work in the software industry, while those with abilities $q \in\left(q_{a}, q_{b}\right)$ are managers of automobile firms.

Define $q_{w}$ so that $\hat{F}\left(q_{w}\right)-w=w$, where $\hat{F}(z) \equiv \frac{1}{\Phi(\hat{q})} \int_{q_{\min }}^{\hat{q}} F(z, q) d \Phi(q)$ is the expected output of an automobile firm with a manager of talent $z$ when the worker pool includes all individuals with talent 


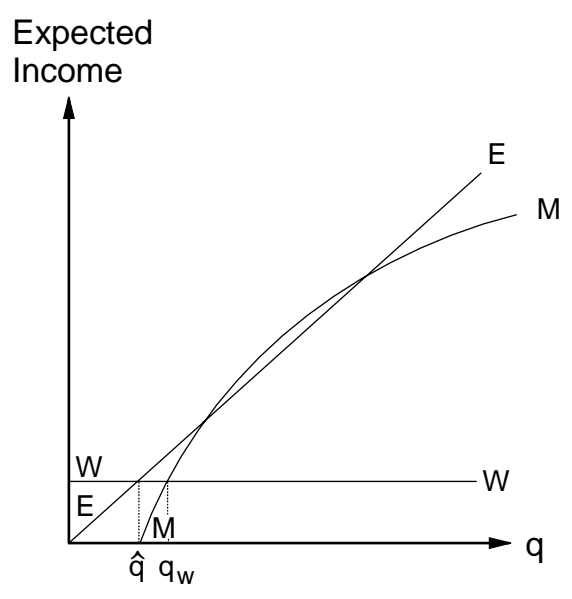

Figure 5: Some Moderately Talented Individuals Prefer Entrepreneurship

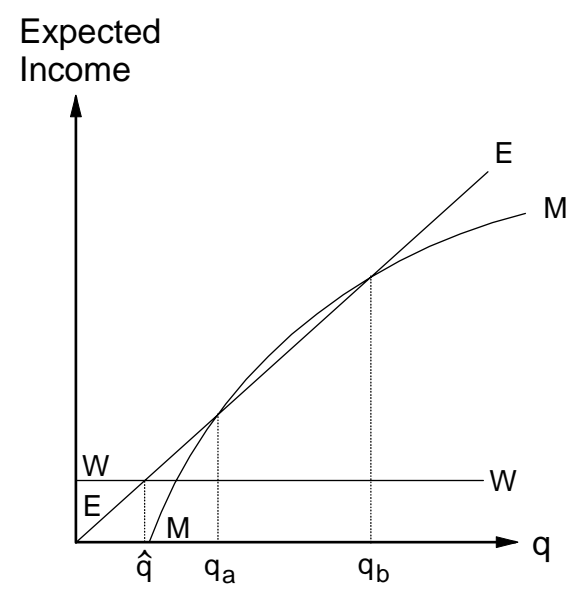

Figure 6: Hypothetical Equilibrium with Two Sets of Entrepreneurs 
between $q_{\min }$ and $\hat{q}$. With this definition, $q_{w}$ is at the intersection of $M M$ and $W W$; therefore $q_{w}>\hat{q}$. Also, the $M M$ curve is steeper at $q_{w}$ than it is at $q_{a}$, and it is steeper at $q_{a}$ than is the $E E$ curve. Therefore, $\hat{F}^{\prime}\left(q_{w}\right)>\lambda p$.

But $q_{w}>\hat{q}$ implies $\hat{F}\left(q_{w}\right) / 2 q_{w}<\lambda p$, by the definitions of $q_{w}$ and $\hat{q}$. Also, the symmetry of $F(\cdot)$ and the fact that it has an elasticity of substitution everywhere less than one implies $q_{w} F_{1}\left(q_{w}, q\right) / F\left(q_{w}, q\right) \leq$ $1 / 2$ for all $q \leq q_{w}$. This in turn implies

$$
\hat{F}^{\prime}\left(q_{w}\right)=\frac{1}{\Phi(\hat{q})} \int_{q_{\min }}^{\hat{q}} F_{1}\left(q_{w}, q\right) d \Phi(q)<\frac{1}{\Phi(\hat{q})} \int_{q_{\min }}^{\hat{q}} \frac{F\left(q_{w}, q\right)}{2 q_{w}} d \Phi(q) d \Phi(q)=\frac{\hat{F}\left(q_{w}\right)}{2 q_{w}} .
$$

Again, we have a contradiction. So there can be no equilibrium of the sort depicted in Figure 6.

\section{Appendix B}

This appendix derives the comparative statics of the model under the assumption of a uniform distribution of talents. In the process, I substantiate the various claims made in the text.

Let $q \sim U\left[q_{\min }, q_{\max }\right]$, where $q_{\min }=\bar{q}-e, q_{\max }=\bar{q}+e$, and $\bar{q}$ is the mean of $q$. Combining (1) and (2), and using the properties of the uniform distribution, we have

$$
\lambda p q_{m}=\frac{1}{q_{w}-q_{\min }} \int_{q_{\min }}^{q_{w}}\left[F\left(q_{m}, q\right)-\frac{F\left(q_{w}, q\right)}{2}\right] d q .
$$

With $q$ uniformly distributed, (3) becomes

$$
q_{m}=2 q_{w}-q_{\min }
$$

Differentiating (A1) and (A2) totally with respect to $p$ gives

$$
\frac{d q_{m}}{d p}=\frac{1}{\Delta}\left(\frac{\lambda q_{m}}{e}\right)
$$

where

$$
\begin{aligned}
\Delta \equiv & -2 \lambda p+ \\
& \frac{1}{q_{w}-q_{\min }}\left\{\int_{q_{\min }}^{q_{w}}\left[2 F_{1}\left(q_{m}, q\right)-\frac{F_{1}\left(q_{w}, q\right)}{2}\right] d q-\tilde{F}\left(q_{m}\right)+\frac{\tilde{F}\left(q_{w}\right)}{2}+F\left(q_{m}, q_{w}\right)-f q_{w}\right\}
\end{aligned}
$$

and $\tilde{F}(z)=\frac{1}{q_{w}-q_{\min }} \int_{q_{\min }}^{q_{w}} F(z, q) d q$ is the expected output for a manager of ability $z$.

First I will establish that $\Delta<0$. To this end, I use (A1) to solve for $\lambda p$, and substitute the result in (A4), to derive ${ }^{20}$

$$
\begin{aligned}
\frac{q_{m}\left(q_{w}-q_{\min }\right)}{q_{\min }} \Delta & =-\tilde{F}\left(q_{m}\right)+\frac{3 q_{w}-2 q_{\min }}{2 q_{w}} \tilde{F}\left(q_{w}\right)-F\left(q_{m}, q_{w}\right)+2 F\left(q_{m}, q_{\min }\right)-\frac{q_{m}}{2 q_{w}} F\left(q_{w}, q_{\min }\right) \\
& =\Delta_{1}+\Delta_{2}+\Delta_{3}+\Delta_{4}+\Delta_{5},
\end{aligned}
$$

\footnotetext{
${ }^{20}$ Note that Euler's theorem and integration by parts gives

$$
\int_{q_{\min }}^{q_{w}} F_{1}(z, q) d q=\frac{1}{z}\left[2\left(q_{w}-q_{\min }\right) \tilde{F}(z)-q_{w} F\left(z, q_{w}\right)+q_{\min } F\left(z, q_{\min }\right)\right] .
$$
}


where

$$
\begin{gathered}
\Delta_{1} \equiv F\left(q_{m}, q_{\min }\right)+F\left(q_{w}, q_{w}\right)-F\left(q_{m}, q_{w}\right)-F\left(q_{w}, q_{\min }\right) \\
\Delta_{2} \equiv \tilde{F}\left(q_{w}\right)+F\left(q_{m}, q_{\min }\right)-\tilde{F}\left(q_{m}\right)-F\left(q_{w}, q_{\min }\right) \\
\Delta_{3} \equiv \frac{1}{2}\left[\tilde{F}\left(q_{w}\right)-F\left(q_{w}, q_{w}\right)\right] \\
\Delta_{4} \equiv \frac{q_{\min }}{2 q_{w}}\left[F\left(q_{w}, q_{\min }\right)+F\left(q_{w}, q_{w}\right)-2 \tilde{F}\left(q_{w}\right)\right] \\
\Delta_{5} \equiv \frac{1}{2}\left[2 F\left(q_{w}, q_{\min }\right)-F\left(q_{w}, q_{w}\right)-F\left(q_{\min }, q_{\min }\right)\right]
\end{gathered}
$$

Now, $\Delta_{1}, \Delta_{2}$, and $\Delta_{5}$ are negative by the supermodularity of $F(\cdot), \Delta_{3}$ is negative because $q_{w} \geq q$ for all $q \in\left[q_{\min }, q_{w}\right]$, and $\Delta_{4}$ is negative because $F_{12}\left(q_{w}, q\right)>0$ and $F(\cdot)$ homogeneous of degree one implies $F_{22}\left(q_{w}, q\right)<0$ for $q \in\left[q_{\min }, q_{w}\right]$. Thus, $\Delta<0$.

With $\Delta<0$, (A3) implies $d q_{m} / d p<0$. But the output of software is inversely related to $q_{m}$; $x_{s}=\frac{\lambda L}{2 e} \int_{q_{m}}^{q_{\max }} q d q$. Therefore, $d x_{s} / d p>0$.

Also, $d q_{w} / d p=\left(d q_{m} / d p\right) / 2$. Therefore, $d q_{w} / d p<0$. From (1) and the properties of the uniform distribution, we have

$$
w=\frac{\tilde{F}\left(q_{w}\right)}{2}
$$

Then $\partial w / \partial q_{w}>0$, which means that $d w / d p<0$.

Now I differentiate (A1) and (A2) with respect to $e$, holding $p$ constant. After some rearranging, this yields

$$
\begin{aligned}
\frac{d q_{m}}{d e}= & \frac{1}{\left(q_{w}-q_{\min }\right) \Delta} \times \\
& {\left[\tilde{F}\left(q_{m}\right)-\frac{\tilde{F}\left(q_{w}\right)}{2}-F\left(q_{m}, q_{\min }\right)-\frac{F\left(q_{w}-q_{\min }\right)}{2}+F\left(q_{m}, q_{w}\right)-f q_{w}-\int_{q_{\min }}^{q_{w}} \frac{F_{1}\left(q_{w}, q\right)}{2} d q\right] . }
\end{aligned}
$$

Using the definition of $\Delta$, the expression for $\lambda p$ from (A1) and the relationship between $q_{m}$ and $q_{w}$ from (A2), I calculate

$$
\frac{d q_{m}}{d e}+1=\frac{-2}{\Delta}\left\{\frac{2 F\left(q_{m}, q_{\min }\right)}{q_{m}}-\frac{\left[F\left(q_{m}, q_{w}\right)+\tilde{F}\left(q_{m}\right)\right]}{q_{m}}-\frac{F\left(q_{w}, q_{\min }\right)}{2 q_{w}}+\left[\frac{1}{q_{w}}-\frac{1}{2 q_{m}}\right] \tilde{F}\left(q_{w}\right)\right\}
$$

or

$$
\frac{d q_{m}}{d e}+1=\frac{-2}{\Delta}\left\{\frac{q_{w}-q_{\min }}{q_{\min }} \Delta-\frac{1}{2 q_{w}}\left[F\left(q_{m}, q_{\min }\right)-F\left(q_{w}, q_{\min }\right)\right]\right\} .
$$

Note that $-2 / \Delta>0$, while $\Delta<0$ and $q_{m}>q_{w}$, which implies that the term in curly brackets in (A5) is negative. Therefore, $d q_{m} / d e+1<0$ and, a fortiori, $d q_{m} / d e<0$.

From $x_{s}=\frac{\lambda L}{2 e} \int_{q_{m}}^{q_{\max }} q d q=\lambda L\left[(\bar{q}+e)^{2}-q_{m}^{2}\right] / 4 e$, I compute

$$
\frac{d x_{s}}{d e}=\frac{\lambda L}{4 e^{2}}\left[q_{m}^{2}+e^{2}-\bar{q}^{2}-2 e q_{m} \frac{d q_{m}}{d e}\right] .
$$


But $q_{m}>q_{\min }=\bar{q}-e$ implies $e q_{m}>e \bar{q}-e^{2}$ and $q_{m}^{2}>\bar{q}^{2}-2 \bar{q} e+e^{2}$. Therefore,

$$
\frac{d x_{s}}{d e}>\frac{\lambda L}{4 e^{2}}\left[2 e^{2}-2 \bar{q} e-2 e(\bar{q}-e) \frac{d q_{m}}{d e}\right]=-\lambda L \frac{\bar{q}-e}{2 e}\left[\frac{d q_{m}}{d e}+1\right] .
$$

So $d q_{m} / d e+1<0$ implies $d x_{s} / d e>0$; i.e., a spread in the distribution of talent increases equilibrium output of software.

Output of automobiles is given by

$$
x_{a}=\frac{L}{2 e\left(q_{w}-q_{\min }\right)} \int_{q_{w}}^{q_{m}} \int_{q_{\min }}^{q_{w}} F(z, q) d q d z
$$

From this I compute

$$
\begin{aligned}
\frac{d x_{a}}{d e}= & -\frac{x_{a}}{e\left(q_{w}-q_{\min }\right)}\left[e+q_{w}-q_{\min }\right]+ \\
& \frac{L}{2 e\left(q_{w}-q_{\min }\right)}\left\{\left[\int_{q_{w}}^{q_{m}} F\left(z, q_{w}\right) d z\right] \frac{d q_{w}}{d e}+\int_{q_{w}}^{q_{m}} F\left(z, q_{\min }\right) d z\right\}+ \\
& \frac{L}{2 e}\left[\tilde{F}\left(q_{m}\right) \frac{d q_{m}}{d e}-\tilde{F}\left(q_{w}\right) \frac{d q_{w}}{d e}\right]
\end{aligned}
$$

Note from (A2) and $q_{m}=\bar{q}-e$ that

$$
\frac{d q_{w}}{d e}=\frac{1}{2} \frac{d q_{m}}{d e}-\frac{1}{2}
$$

With $d q_{m} / d e<-1$, this implies $d q_{m} / d e<d q_{w} / d e<-1$.

The term on the first line on the right-hand side of (A6) is negative, because $q_{w}>q_{\text {min }}$. The term on the second line of $(\mathrm{A} 6)$ is negative, because $F\left(z, q_{w}\right)>F\left(z, q_{\min }\right)$ and $d q_{w} / d e<-1$. The term on the third line of (A6) is negative, because $\tilde{F}\left(q_{m}\right)>\tilde{F}\left(q_{w}\right)$ and $d q_{m} / d e<d q_{w} / d e<0$. I conclude that $d x_{a} /$ de $<0$; i.e., a spread in the distribution of talent reduces equilibrium output of automobiles.

Since $d x_{s} / d e>0$ and $d x_{a} / d e<0, d\left(x_{s} / x_{a}\right) / d e>0$. That is, a spread in the distribution of talent increases relative output of software at a given price. It follows that a country with a more diverse labor force produces relatively more software in a free-trade equilibrium. With identical and homothetic preferences, this country must export software and import automobiles. 


\section{CESifo Working Paper Series}

677 Kai Sülzle and Achim Wambach, Insurance in a Market for Credence Goods, February 2002

678 Paul de Bijl and Martin Peitz, New Competition in Telecommunications Markets: Regulatory Pricing Principles, March 2002

679 Tilman Börgers and Christian Dustmann, Rationalizing the UMTS Spectrum Bids: the Case of the UK Auction, March 2002

680 Christian Ewerhart and Benny Moldovanu, The German UMTS Design: Insights From Multi-Object Auction Theory, March 2002

681 Gebhard Flaig, Unobserved Components Models for Quarterly German GDP, March 2002

682 Steffen H. Hoernig and Tommaso M. Valletti, The Interplay Between Regulation and Competitions: The Case of Universal Service Obligations, March 2002

683 Jörg Baten, Did Partial Globalization Increase Inequality? Did Inequality Stimulate Globalization Backlash? The case of the Latin American Periphery, 1950-80, March 2002

684 Norman Loayza and Romain Ranciere, Financial Development, Financial Fragility, and Growth, March 2002

685 Thomas Eichner and Andreas Wagener, Increases in Risk and the Welfare State, March 2002

686 Hyun Park and Apostolis Philippopoulos, Can Poductive Government Spending be the Engine of Long-Run Growth When Labor Supply is Engogenous?, March 2002

687 Jonathan P. Thomas and Tim Worrall, Gift-Giving, Quasi-Credit and Reciprocity, March 2002

688 Barbara Buchner, Carlo Carraro, Igor Cersosimo, and Carmen Marchiori, Back to Kyoto? US Participation and the Linkage between R\&D and Climate Cooperation, March 2002

689 Amihai Glazer and Vesa Kanniainen, The Effects of Employment Protection on the Choice of Risky Projects, March 2002

690 Michael Funke and Annekatrin Niebuhr, Threshold Effects and Regional Economic Growth - Evidence from West Germany, March 2002

691 George Economides, Apostolis Philippopoulos, and Simon Price, Elections, Fiscal Policy and Growth: Revisiting the Mechanism, March 2002 
692 Amihai Glazer, Vesa Kanniainen, and Mikko Mustonen, Innovation of Network Goods: A Non-Innovating Firm Will Gain, March 2002

693 Helmuth Cremer, Jean-Marie Lozachmeur, and Pierre Pestieau, Social Security, Retirement Age and Optimal Income Taxation, April 2002

694 Rafael Lalive and Josef Zweimüller, Benefit Entitlement and the Labor Market: Evidence from a Large-Scale Policy Change, April 2002

695 Hans Gersbach, Financial Intermediation and the Creation of Macroeconomic Risks, April 2002

696 James M. Malcomson, James W. Maw, and Barry McCormick, General Training by Firms, Apprentice Contracts, and Public Policy, April 2002

697 Simon Gächter and Arno Riedl, Moral Property Rights in Bargaining, April 2002

698 Kai A. Konrad, Investment in the Absence of Property Rights: The Role of Incumbency Advantages, April 2002

699 Campbell Leith and Jim Malley, Estimated General Equilibrium Models for the Evaluation of Monetary Policy in the US and Europe, April 2002

700 Yin-Wong Cheung and Jude Yuen, Effects of U.S. Inflation on Hong Kong and Singapore, April 2002

701 Henry Tulkens, On Cooperation in Musgravian Models of Externalities within a Federation, April 2002

702 Ralph Chami and Gregory D. Hess, For Better or For Worse? State-Level Marital Formation and Risk Sharing, April 2002

703 Fredrik Andersson and Kai A. Konrad, Human Capital Investment and Globalization in Extortionary States, April 2002

704 Antonis Adam and Thomas Moutos, The Political Economy of EU Enlargement: Or, Why Japan is not a Candidate Country?, April 2002

705 Daniel Gros and Carsten Hefeker, Common Monetary Policy with Asymmetric Shocks, April 2002

706 Dirk Kiesewetter and Rainer Niemann, Neutral and Equitable Taxation of Pensions as Capital Income, April 2002

707 Robert S. Chirinko, Corporate Taxation, Capital Formation, and the Substitution Elasticity between Labor and Capital, April 2002

708 Frode Meland and Gaute Torsvik, Structural Adjustment and Endogenous Worker Recall Probabilities, April 2002 
709 Rainer Niemann and Caren Sureth, Taxation under Uncertainty - Problems of Dynamic Programming and Contingent Claims Analysis in Real Option Theory, April 2002

710 Thomas Moutos and William Scarth, Technical Change and Unemployment: Policy Responses and Distributional Considerations, April 2002

711 Günther Rehme, (Re-)Distribution of Personal Incomes, Education and Economic Performance Across Countries, April 2002

712 Thorvaldur Gylfason and Gylfi Zoega, Inequality and Economic Growth: Do Natural Resources Matter?, April 2002

713 Wolfgang Leininger, Contests over Public Goods: Evolutionary Stability and the FreeRider Problem, April 2002

714 Ernst Fehr and Armin Falk, Psychological Foundations of Incentives, April 2002

715 Giorgio Brunello, Maria Laura Parisi, and Daniela Sonedda, Labor Taxes and Wages: Evidence from Italy, May 2002

716 Marta Aloi and Huw Dixon, Entry Dynamics, Capacity Utilisation and Productivity in a Dynamic Open Economy, May 2002

717 Paolo M. Panteghini, Asymmetric Taxation under Incremental and Sequential Investment, May 2002

718 Ben J. Heijdra, Christian Keuschnigg, and Wilhelm Kohler, Eastern Enlargement of the EU: Jobs, Investment and Welfare in Present Member Countries, May 2002

719 Tapio Palokangas, The Political Economy of Collective Bargaining, May 2002

720 Gilles Saint-Paul, Some Evolutionary Foundations for Price Level Rigidity, May 2002

721 Giorgio Brunello and Daniela Sonedda, Labor Tax Progressivity, Wage Determination, and the Relative Wage Effect, May 2002

722 Eric van Damme, The Dutch UMTS-Auction, May 2002

723 Paolo M. Panteghini, Endogenous Timing and the Taxation of Discrete Investment Choices, May 2002

724 Achim Wambach, Collusion in Beauty Contests, May 2002

725 Dominique Demougin and Claude Fluet, Preponderance of Evidence, May 2002

726 Gilles Saint-Paul, Growth Effects of Non Proprietary Innovation, May 2002

727 Subir Bose, Gerhard O. Orosel, and Lise Vesterlund, Optimal Pricing and Endogenous Herding, May 2002 
728 Erik Leertouwer and Jakob de Haan, How to Use Indicators for 'Corporatism' in Empirical Applications, May 2002

729 Matthias Wrede, Small States, Large Unitary States and Federations, May 2002

730 Christian Schultz, Transparency and Tacit Collusion in a Differentiated Market, May 2002

731 Volker Grossmann, Income Inequality, Voting Over the Size of Public Consumption, and Growth, May 2002

$732 \mathrm{Yu}-\mathrm{Fu}$ Chen and Michael Funke, Working Time and Employment under Uncertainty, May 2002

733 Kjell Erik Lommerud, Odd Rune Straume, and Lars Sørgard, Downstream Merger with Oligopolistic Input Suppliers, May 2002

734 Saku Aura, Does the Balance of Power Within a Family Matter? The Case of the Retirement Equity Act, May 2002

735 Sandro Brusco and Fausto Panunzi, Reallocation of Corporate Resources and Managerial Incentives in Internal Capital Markets, May 2002

736 Stefan Napel and Mika Widgrén, Strategic Power Revisited, May 2002

737 Martin W. Cripps, Godfrey Keller, and Sven Rady, Strategic Experimentation: The Case of Poisson Bandits, May 2002

738 Pierre André Chiappori and Bernard Salanié, Testing Contract Theory: A Survey of Some Recent Work, June 2002

739 Robert J. Gary-Bobo and Sophie Larribeau, A Structural Econometric Model of Price Discrimination in the Mortgage Lending Industry, June 2002

740 Laurent Linnemer, When Backward Integration by a Dominant Firm Improves Welfare, June 2002

741 Gebhard Kirchgässner and Friedrich Schneider, On the Political Economy of Environmental Policy, June 2002

742 Christian Keuschnigg and Soren Bo Nielsen, Start-ups, Venture Capitalits, and the Capital Gains Tax, June 2002

743 Robert Fenge, Silke Uebelmesser, and Martin Werding, Second-best Properties of Implicit Social Security Taxes: Theory and Evidence, June 2002

744 Wendell Fleming and Jerome Stein, Stochastic Optimal Control, International Finance and Debt, June 2002

745 Gene M. Grossman, The Distribution of Talent and the Pattern and Consequences of International Trade, June 2002 